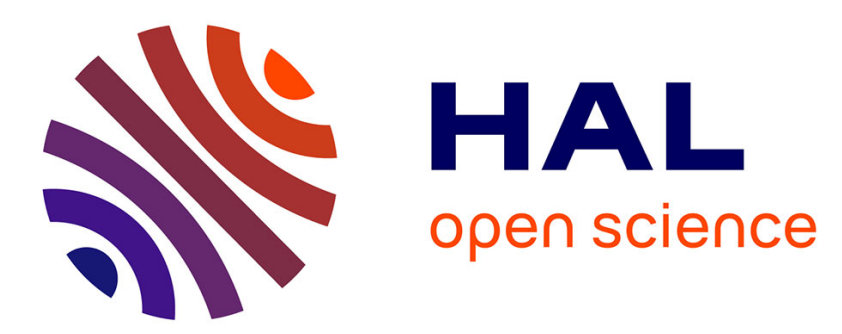

\title{
Filtration of airborne particles by a trickle granular bed: a modelling approach
}

Nassim Khirouni, Augustin Charvet, Dominique Thomas

\section{To cite this version:}

Nassim Khirouni, Augustin Charvet, Dominique Thomas. Filtration of airborne particles by a trickle granular bed: a modelling approach. Environmental Technology, 2020, 41 (25), pp.3387-3395. 10.1080/09593330.2019.1609592. hal-02974854

\section{HAL Id: hal-02974854 \\ https://hal.science/hal-02974854}

Submitted on 22 Oct 2020

HAL is a multi-disciplinary open access archive for the deposit and dissemination of scientific research documents, whether they are published or not. The documents may come from teaching and research institutions in France or abroad, or from public or private research centers.
L'archive ouverte pluridisciplinaire HAL, est destinée au dépôt et à la diffusion de documents scientifiques de niveau recherche, publiés ou non, émanant des établissements d'enseignement et de recherche français ou étrangers, des laboratoires publics ou privés. 


\title{
Filtration of airborne particles by a trickle granular bed: A modelling approach
}

\author{
KHIROUNI N.*, CHARVET A. and THOMAS D.
}

\author{
Laboratoire Réactions et Génie des Procédés, Université de Lorraine, CNRS, LRGP, F-54000 Nancy, \\ France
}

*Corresponding author:

E-Mail: nassim.khirouni@univ-lorraine.fr

\begin{abstract}
The removal of airborne particles was investigated using a trickle granular bed. This filtration process maintains a constant pressure drop during particles loading, which makes it an interesting alternative for aerosol filtration. In order to establish mathematical models for the design of the process, a modelling approach that takes into account the changes of the bed characteristics due to the liquid hold up is undertaken. This approach allows predicting the pressure drop and the filtration efficiency of the trickle granular bed, based on the assumption that the bed porosity decreases and the collectors diameter increases with increasing the liquid flow rate. The model predictions are in agreement with experimental data. For particles with diameters around $100 \mathrm{~nm}$ the collection efficiency presents a minimum. For smaller particles the collection efficiency increases as the dominating collection mechanism is Brownian diffusion. In the micronic range the collection is governed by inertial and interception mechanisms and consequently increases with increasing the particle size.
\end{abstract}

KEYWORDS : Particles - Filtration - Trickle bed - Pressure drop - Collection efficiency filters

\section{INTRODUCTION}

Airborne particles, generated by several processes like combustion, thermal spraying, grinding and others, present serious health hazards and potential negative impact on the environment. Dust filtration can be achieved by cyclones, wet separators, electrostatic precipitators or filters. The most effective separation processes are fibrous media but the main issue encountered is the filter rapid clogging and the increase of the pressure drop. Moreover, unclogging operations are not fully efficient and might cause the deterioration of the filter structure leading to a decrease in its performances [1]. In the case of metallic nanoparticles the clogging can be irreversible, inducing a regular replacement of the filter and higher operational costs [2]. For these reasons research for alternative separation processes is gaining more and more attention. Among them is the granular bed which offers interesting advantages, such as operating at high temperatures, chemical resistance, low cost and the possibility to regenerate the bed. Several investigations showed that the granular bed could be a promising technique for the removal of ultrafine particles $[3,4,5]$. In this perspective, the trickle granular bed represents an innovative solution to avoid clogging and thus having a continuous process with a constant pressure drop. Indeed, the trickling liquid flows in the form of films over the collectors surface which allows a continuous entrainment of the particles collected. As high efficiency of a trickle bed towards micronic particles has been proved in an earlier work [6], the aim of this study is to evaluate its performances for nanoparticles filtration and to establish mathematical models for the scale up of this equipment. The modelling of the process performances is done by assuming that the liquid accumulation in the bed, also known as the liquid hold up, would alter the bed characteristics. This liquid accumulation would decrease the bed porosity and increase the collectors diameter, consequently modify the pressure drop and the collection efficiency of the trickle granular bed. Therefore it is important to estimate the liquid hold up as it is related to these changes. The hydrodynamics of trickle beds have been well studied in the course of the past years, and one could find numerous correlations for predicting the liquid hold up [7], however these correlations are restricted to the operating conditions considered by their authors and are sensitive to the flow regime. For dust filtration applications, the trickle granular bed was designed to operate only in the trickling regime, i.e. at low liquid and gas flow rates. The trickle flow regime is generally achieved for a liquid superficial velocity smaller than $0.01 \mathrm{~m} \cdot \mathrm{s}^{-1}$ and a gas velocity 
lower than $0.8 \mathrm{m.s}^{-1}$ [8]. In this hydrodynamic regime, the liquid forms a film over the solid collectors and can continuously remove captured particles from the collectors surface while maintaining a limited pressure drop.

\section{I- MODELLING}

The modelling of the pressure drop and the collection efficiency of the trickle bed is based on the variation of the bed porosity and the collectors diameter due to the liquid hold up. The latter hypothesis is valid in the trickling regime because the liquid flows in the form of films over the collectors. This approach is undertaken for spherical collectors. The liquid hold up, noted h, represents the amount of liquid held in the bed per unit bed volume:

$$
\mathrm{h}=\frac{\mathrm{V}_{\mathrm{L}}}{\mathrm{V}_{\mathrm{bed}}}
$$

where $V_{L}$ is the total liquid volume retained in the bed and $V_{\text {bed }}$ is the bed volume.

For non-porous packings, the total liquid hold up is the sum of two contributions. On the one hand, the static liquid hold up represents the stagnant liquid, i.e. the liquid retained between and around the contact points of the collectors after draining the bed. On the other hand, the dynamic liquid hold up, which represents the free flowing fraction of the liquid that drains from the bed when the liquid inlet is shut off.

$$
\mathrm{h}=\mathrm{h}_{\mathrm{s}}+\mathrm{h}_{\mathrm{dyn}}
$$

where $h_{s}$ is the static liquid hold up and $h_{\text {dyn }}$ the dynamic liquid hold up.

The liquid hold up would decrease the bed porosity as the water will occupy a fraction of the void volume. The wet porosity $\varepsilon_{\mathrm{w}}$ can be calculated as follows:

$$
\varepsilon_{\mathrm{W}}=\varepsilon-\mathrm{h}
$$

where $\varepsilon$ is the dry bed porosity.

The determination of the wet collector diameter is done by assuming that the liquid is homogeneously distributed over the bed and that all the collectors are perfectly wetted. The volume of liquid around a single collector $\mathrm{V}_{\mathrm{LC}}$ is calculated as follows:

$$
\mathrm{V}_{\mathrm{LC}}=\frac{\mathrm{V}_{\mathrm{L}}}{\mathrm{N}_{\mathrm{C}}}=\frac{\mathrm{h} \mathrm{V}_{\text {bed }}}{\mathrm{N}_{\mathrm{C}}}
$$

where $\mathrm{V}_{\mathrm{L}}$ is the total liquid volume retained in the bed and $N_{C}$ is the number of collectors in the bed, which is calculated using the following relation:

$$
\mathrm{N}_{\mathrm{C}}=\frac{\mathrm{V}_{\text {bed }}(1-\varepsilon)}{\mathrm{V}_{\mathrm{C}}}
$$

where $V_{C}$ is the single collector volume. This means that:

$$
\mathrm{V}_{\mathrm{LC}}=\frac{\mathrm{h}}{1-\varepsilon} \frac{\pi}{6} \mathrm{~d}_{\mathrm{C}}^{3}
$$

with $d_{c}$ is the collector diameter. Another way to express the volume of liquid around a single collector can be defined as follows:

$$
\mathrm{V}_{\mathrm{LC}}=\frac{\pi}{6} \mathrm{~d}_{\mathrm{CW}}^{3}-\frac{\pi}{6} \mathrm{~d}_{\mathrm{C}}^{3}
$$

where $d_{c w}$ represents the wet collector diameter. By combining equations 6 and 7 , the final wet collector diameter expression is:

$$
\mathrm{d}_{\mathrm{CW}}=\mathrm{d}_{\mathrm{C}}\left(1+\frac{\mathrm{h}}{(1-\varepsilon)}\right)^{\frac{1}{3}}
$$

\subsection{Pressure drop}

In order to estimate the pressure drop through the trickle bed, the Ergun [9] equation was used taking into account the changes of the bed porosity and the collectors diameter due to the liquid hold up. For this, the wet porosity and the wet collector diameter expressions are used under the assumption that the liquid is homogeneously distributed over the bed. For the constant $k_{1}$ of the Ergun equation (cf. Equation 9), generally correlated to the bed porosity, the Ingmanson and Andrew [10] expression (cf. Equation 10 ), which is valid for a porosity between 0.4 and 0.9 , has been used. Still these correlations have been developed for dry beds. In the presence of liquid the bed porosity decreases to values between 0.2 and 0.3 and the retained liquid would create obstacles for the gas flow, inducing an increase of the tortuosity. So, it was important to establish a relation between the constant $k_{2}$ and the changing bed characteristics with the liquid hold up. Using experimental measurements of the pressure drop the constant $k_{2}$ was correlated to the wet collector diameter and the wet porosity (cf. Equation 11). Specchia and Baldi [11] also reported a variation of the constants $k_{1}$ and $k_{2}$ after measuring the pressure drop of wet beds. They attributed the difference compared to dry beds to the fact that wetting would change the packing shape. The model given by equation 9 would allow to describe the pressure drop for various liquid and air flow rates.

$$
\begin{gathered}
\frac{\Delta \mathrm{P}}{\mathrm{H}}=\mathrm{k}_{1} \frac{\left(1-\varepsilon_{\mathrm{W}}\right)^{2}}{\mathrm{~d}_{\mathrm{CW}}^{2} \varepsilon_{\mathrm{W}}^{3}} \mu_{\mathrm{G}} \mathrm{U}_{\mathrm{G}} \\
+\mathrm{k}_{2} \frac{1-\varepsilon_{\mathrm{W}}}{\mathrm{d}_{\mathrm{CW}} \varepsilon_{\mathrm{W}}^{3}} \rho_{\mathrm{G}} \mathrm{U}_{\mathrm{G}}^{2} \\
\mathrm{k}_{1}=36 \frac{3.5 \varepsilon_{\mathrm{W}}^{3}}{\left(1-\varepsilon_{\mathrm{W}}\right)^{0.5}}\left[1+57\left(1-\varepsilon_{\mathrm{W}}\right)^{3}\right] \\
\mathrm{k}_{2}=7\left(\frac{\mathrm{d}_{\mathrm{CW}}}{\mathrm{d}_{\mathrm{C}}}\right)^{2} \frac{\varepsilon_{\mathrm{W}}}{\left(1-\varepsilon_{\mathrm{W}}\right)^{2}}
\end{gathered}
$$




\subsection{Trickle bed collection efficiency}

The expressions used for the calculation of the collection efficiency of dry granular beds are modified for the trickle granular bed using the wet porosity and the wet collector diameter. The trickle bed filtration efficiency $\mathrm{E}_{\mathrm{TB}}$ is given by equation 12 [12]:

$$
\mathrm{E}_{\mathrm{TB}}=1-\exp \left(-\frac{3}{2} \frac{\left(1-\varepsilon_{\mathrm{W}}\right) \mathrm{H}}{\mathrm{d}_{\mathrm{CW}}} \eta_{\mathrm{T}}\right)
$$

Another expression could be used based on the isolated sphere model $[13,14]$, obtained by multiplying the collector diameter in equation 12 by the porosity. where $\mathrm{H}$ is the bed thickness and $\eta_{T}$ the overall efficiency of a single collector, expressed as follows:

$$
\eta_{\mathrm{T}}=1-\prod\left(1-\eta_{\mathrm{i}}\right)
$$

where $\eta_{i}$ is the efficiency of each mechanism. For nanoparticles the dominating mechanism is diffusion. Whereas in the micronic range, the collection mechanisms involved are: interception, inertial impaction and sedimentation. The models used for the different collection mechanisms are resumed in table 1.

\begin{tabular}{|c|c|c|c|}
\hline Mechanism & Parameter & Model & Validity domain \\
\hline Diffusion & $\begin{aligned} \mathrm{Pe} & =\frac{\mathrm{U}_{\mathrm{G}} \mathrm{d}_{\mathrm{CW}}}{\mathrm{D}_{\text {diff }}} \\
\mathrm{D}_{\text {diff }} & =\frac{\mathrm{k}_{\mathrm{B}} \mathrm{TCu}}{3 \pi \mu_{\mathrm{G}} \mathrm{d}_{\mathrm{p}}}\end{aligned}$ & $\begin{array}{l}\eta_{\text {Diffusion }}=4 \mathrm{~g}\left(\varepsilon_{\mathrm{W}}\right) \mathrm{Pe}^{-2 / 3} \text { with } \\
\mathrm{g}\left(\varepsilon_{\mathrm{W}}\right)=\frac{1.09}{\varepsilon_{\mathrm{W}}} \\
{[15]}\end{array}$ & $\begin{array}{l}\operatorname{Re}<10 \\
0.35<\varepsilon<0.7\end{array}$ \\
\hline Interception & $\mathrm{R}=\frac{\mathrm{d}_{\mathrm{p}}}{\mathrm{d}_{\mathrm{CW}}}$ & $\begin{array}{l}\eta_{\text {Interception }}=1.5 \mathrm{~g}\left(\varepsilon_{\mathrm{W}}\right)^{3} \mathrm{R}^{2} \\
\text { with } \mathrm{g}\left(\varepsilon_{\mathrm{W}}\right)=\frac{1.09}{\varepsilon_{\mathrm{W}}} \\
\text { nanostructured particles [12] } \\
\eta_{\text {Interception }}=16 \mathrm{R}^{2-\frac{\mathrm{Re}}{\left(R e^{1 / 3}+1\right)^{3}}} \\
\text { with } \mathrm{Re}=\frac{\rho_{\mathrm{G}} \mathrm{U}_{\mathrm{G}} \mathrm{d}_{\mathrm{CW}}}{\mu_{\mathrm{G}}} \text { for micronic } \\
\text { particles [16] }\end{array}$ & $\begin{array}{l}\operatorname{Re}<10 \\
0.35<\varepsilon<0.7\end{array}$ \\
\hline $\begin{array}{l}\text { Inertial } \\
\text { impaction }\end{array}$ & $\mathrm{St}=\frac{\mathrm{Cu} \rho_{\mathrm{p}} \mathrm{d}_{\mathrm{p}}^{2} \mathrm{U}_{\mathrm{G}}}{9 \mu_{\mathrm{G}} \mathrm{d}_{\mathrm{CW}}}$ & $\begin{array}{l}\eta_{\text {Inertial }}=\frac{S_{\text {eff }}^{3}}{0.014+\mathrm{St}_{\text {eff }}^{3}} \quad \text { with } \\
\mathrm{St}_{\text {eff }}=\operatorname{St}\left(1+\frac{1.75 R e \varepsilon_{W}}{150\left(1-\varepsilon_{W}\right)}\right) \text { and } \\
\operatorname{Re}=\frac{\rho_{G} U_{G} d_{C W}}{\mu_{G}} \\
{[16]}\end{array}$ & $\mathrm{St}_{\mathrm{eff}}<0.02$ \\
\hline Sedimentation & $\mathrm{Gr}=\frac{\mathrm{Cu}\left(\rho_{\mathrm{p}}-\rho_{\mathrm{G}}\right) \mathrm{d}_{\mathrm{p}}^{2} \mathrm{~g}}{18 \mu_{\mathrm{G}} \mathrm{U}_{\mathrm{G}}}$ & $\begin{array}{l}\eta_{\text {Sedimentation }}=\frac{\mathrm{Gr}}{1+\mathrm{Gr}} \\
{[17]}\end{array}$ & Theoretical model \\
\hline
\end{tabular}

Table1: Collection efficiency models by the different mechanisms.

\section{II- MATERIALS AND METHODS}

The experimental setup shown in figure 1 is composed of a glass column with a $0.2-\mathrm{m}$ diameter and a $2.5-\mathrm{m}$ height, packed with spherical glass collectors with a porosity close to 0.4 . The air is sucked into the room with a ventilator (2BH7510, Gardner Denver $\left.{ }^{\circledR}\right)$ and the flow rate is controlled by a diaphragm (Eletta ${ }^{\circledR}$ ). The water is pumped (Alpha2 L, Grundfos ${ }^{\circledR}$ ) from a tank and homogeneously distributed over the bed cross section from a trough type distributor placed at the top of the column. The liquid flow rate is set by a float flowmeter (Cole Parmer ${ }^{\circledR}$ ).

A hydrodynamic study was first performed to determine the liquid hold up and the pressure drop of the trickle bed. The pressure drop was measured with pressure sensors (Keller ${ }^{\circledR}$ ). The liquid hold up was determined by a drainage method [18]. Once a steady state is achieved, after $30 \mathrm{~min}$, the liquid inlet and outlet valves ( $\mathrm{N}^{\circ} 4$ and $\mathrm{N}^{\circ} 2$, respectively) are shutoff 
simultaneously. The liquid that drains after opening the outlet valve $\mathrm{N}^{\circ} 1$ represents the dynamic hold up, the remaining stagnant liquid is the static hold up. The dynamic liquid hold up was measured using three different collector diameters (2, 5 and $10 \mathrm{~mm})$, with an air flow rate $(G)$ that ranged between 10 and $25 \mathrm{~m}^{3} \cdot \mathrm{h}$ ${ }^{1}$ and a water flow rate (L) between 0 and 20 L. $\mathrm{min}^{-1}$. For each collector diameter, the experiments were performed with three packing thicknesses $(10,30$ and $50 \mathrm{~cm}$ ).

The static liquid hold up was measured at room temperature and atmospheric pressure using another column having a diameter and a height of 78 and 380 $\mathrm{mm}$ respectively. The ratio of the column diameter to the collector diameter is close to the one obtained using the previous column. Initially the column was filled with a known water mass. After immerging the collectors the outlet valve was opened and the drained liquid was recovered and weighed. The difference between the two liquid masses allowed determining the static hold up, while the volumes occupied by the packing and the liquid were used to calculate the porosity. The experiences were performed using collectors of $0.5,0.8,1,1.6,2,3,4.76,5,6.35$ and 10 $\mathrm{mm}$ diameters. Each experiment was repeated at least 6 times.

An aerosol composed of graphite nanostructured particles was generated with an electric spark generator (DNP 2000, $\operatorname{PALAS}^{\circledR}$ ). The number concentrations upstream and downstream of the trickle bed were measured with an electrostatic classifier (Model 3082, TSI $^{\circledR}$ ) coupled with a condensation particle counter (Model 3776, $\mathrm{TSI}^{\circledR}$ ). The particle size distribution presents a median mobility equivalent diameter close to $40 \mathrm{~nm}$ and the upstream number concentration varied with the air flow rate as a result of dilution (cf. figure 2). The filtration experiments were performed using 5-mm diameter glass collectors and the bed thickness was set at $30 \mathrm{~cm}$. The filtration efficiency is determined with the following equation:

$$
\mathrm{E}=1-\frac{\mathrm{C}_{\text {out }}}{\mathrm{C}_{\text {in }}}
$$

where $\mathrm{C}_{\text {out }}$ and $\mathrm{C}_{\text {in }}$ are the concentrations downstream and upstream of the trickle bed.

To only take into account the granular bed efficiency, the single column (without collectors) contribution was quantified, and the bed efficiency (E) was calculated using the following relation:

$$
\mathrm{E}=\frac{\mathrm{E}_{\text {Column with collectors }}-\mathrm{E}_{\text {Column without collectors }}}{1-\mathrm{E}_{\text {Column without collectors }}}
$$

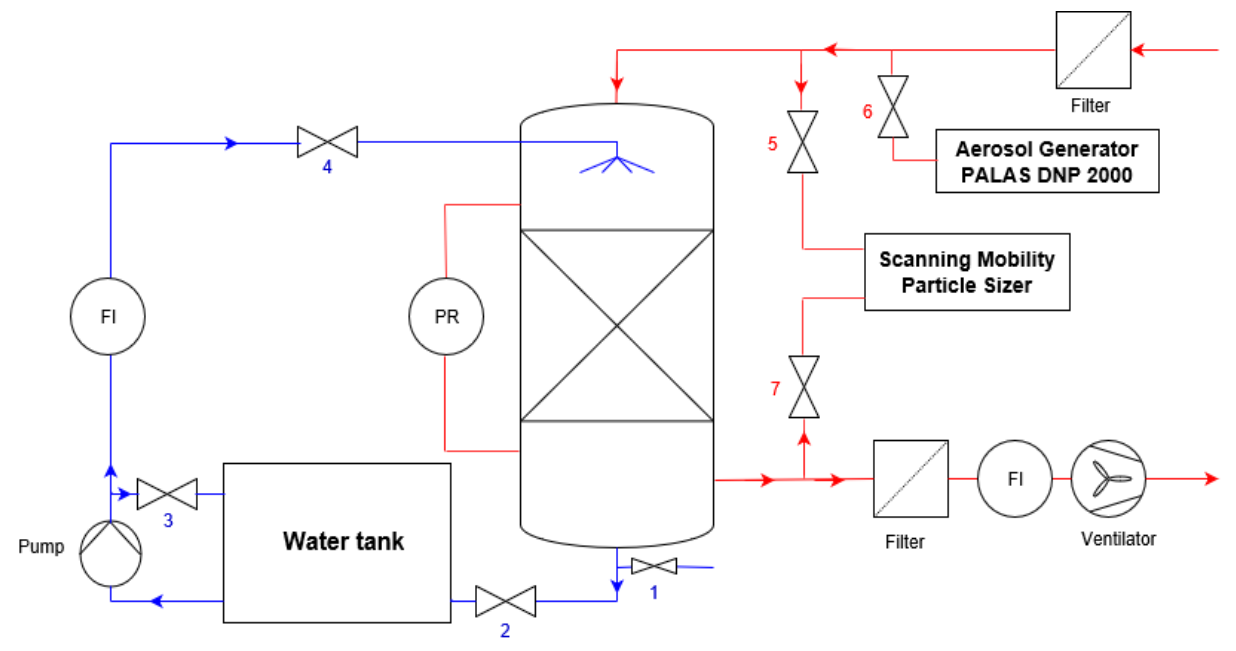

Fig. 1. Experimental pilot. 


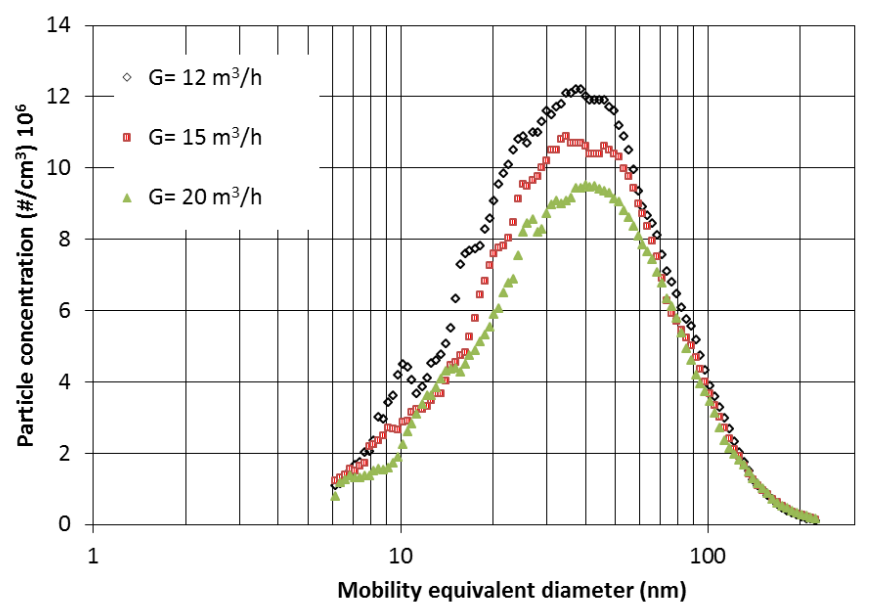

Fig. 2. Number particle size distribution of graphite particles generated.

\section{III- RESULTS AND DISCUSSION}

\subsection{Liquid hold up}

The variation of the static liquid hold up is usually described as a function of the modified Eötvös number EÖ* (equation 16) that takes into account the collector diameter, the bed porosity, the liquid surface tension and density.

$$
E \ddot{O}^{*}=\frac{\rho_{\mathrm{L}}^{2} \mathrm{~g} \mathrm{~d}_{\mathrm{C}}^{2} \varepsilon^{2}}{\sigma_{\mathrm{L}}(1-\varepsilon)^{2}}
$$

The experimental results (fig. 3) show that when the Eötvös number is superior to 0.1 (corresponds to a collector diameter superior to $1 \mathrm{~mm}$ ) the static hold up is constant. For lower values the static hold up increases significantly. The results are compared to correlations proposed in the literature (Table 2), these correlations are strictly empirical.

Table 2. Correlations of the static liquid hold up

\begin{tabular}{lc}
\hline Reference & Correlation \\
\hline$[19]$ & $\mathrm{h}_{\mathrm{s}}=\frac{1}{20+0.9 \mathrm{Eö}^{*}}$ \\
\hline$[20]$ & $\mathrm{h}_{\mathrm{s}}=\frac{0.11}{1+\mathrm{Eö}^{*}}$
\end{tabular}

The predicted values do not agree with the experimental measurements. Since it is crucial for the modelling approach to have an accurate estimation of the static liquid hold up, a correlation derived from data fitting is proposed, given by:

$$
\mathrm{h}_{\mathrm{s}}=0.1023 \exp \left(-13.02 \mathrm{Eö}^{*}\right)+0.0322
$$

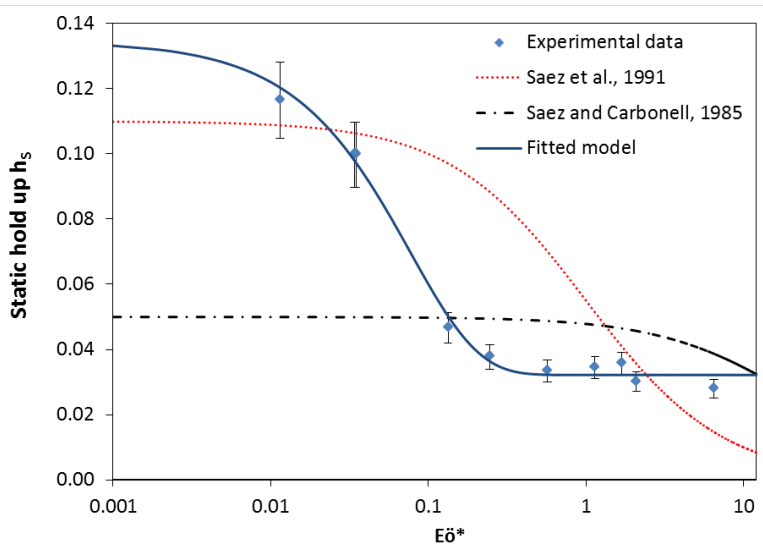

Fig. 3. Results of the static hold up.

As shown by other authors [11,21,22], the measured dynamic liquid hold up is not influenced by the gas flow rate in the studied range $\left(0.08<\mathrm{U}_{\mathrm{G}}<0.2 \mathrm{~m} . \mathrm{s}^{-1}\right.$ and $\left.0.002<\mathrm{U}_{\mathrm{L}}<0.01 \mathrm{~m} . \mathrm{s}^{-1}\right)$. As a consequence, it is described by the power product of the $\operatorname{Re}_{L}\left(\operatorname{Re}_{\mathrm{L}}=\right.$ $\left.\rho_{\mathrm{L}} \mathrm{U}_{\mathrm{L}} \mathrm{d}_{\mathrm{C}} / \mu_{\mathrm{L}}\right), \mathrm{Ga}_{\mathrm{L}}\left(\mathrm{Ga}_{\mathrm{L}}=\rho_{\mathrm{L}}{ }^{2} \mathrm{~g} \mathrm{~d}_{\mathrm{C}}{ }^{3} / \mu_{\mathrm{L}}{ }^{2}\right)$ and the bed characteristics. The obtained model is given by equation 18, which shows that, in this studied flow regime the dynamic liquid hold up is only function of the liquid flow rate and the bed characteristics. Although the correlation is valid in a very narrow range, $4<\mathrm{Re}_{\mathrm{L}}<106$ and $7.8510^{4}<\mathrm{Ga}_{\mathrm{L}}<9.8110^{6}$, but this range includes the operating conditions of the trickle granular bed for dust filtration. Figure 4 gives the comparison between the calculated dynamic liquid hold up and the experimental measurements.

$\mathrm{h}_{\text {dyn }}=1.234 \mathrm{Re}_{\mathrm{L}}^{0.4746} \mathrm{Ga}_{\mathrm{L}}^{-0.314}\left(\mathrm{a}_{\mathrm{s}} \mathrm{d}_{\mathrm{C}}\right)^{0.1613}$ 


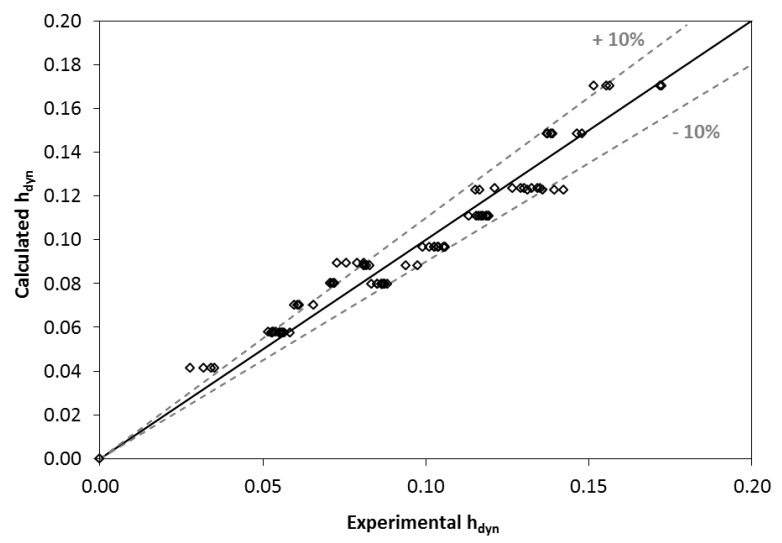

Fig. 4. Parity diagram of the dynamic liquid hold up.
The correlations developed in this study for the prediction of the static and the dynamic liquid hold up give an acceptable error of $10 \%$ which is in the same order of magnitude than the measurements uncertainties. For this reason they will be used directly to calculate the wet porosity and the wet collector diameter. Table 3 resumes the main results as a function of the liquid flow rate:

Table 3. Main results of the variation of the bed characteristics as a function of the liquid flow rate

\begin{tabular}{|c|c|c|c|c|c|c|}
\hline \multirow{2}{*}{$\begin{array}{c}\text { Liquid flow rate } \\
\text { (L.min }^{-1} \text { ) }\end{array}$} & \multicolumn{2}{|c|}{$\mathbf{d}_{\mathrm{C}}=\mathbf{2} \mathbf{~ m m}$} & \multicolumn{2}{c|}{$\mathbf{d}_{\mathrm{C}}=\mathbf{5} \mathbf{~ m m}$} & \multicolumn{2}{c|}{$\mathbf{d}_{\mathrm{C}}=\mathbf{1 0} \mathbf{~ m m}$} \\
\cline { 2 - 7 } & $\boldsymbol{\varepsilon}_{\mathrm{W}}$ & $\mathbf{d}_{\mathrm{cW}} \mathbf{( \mathbf { m m } )}$ & $\boldsymbol{\varepsilon}_{\mathrm{W}}$ & $\left.\mathbf{d}_{\mathbf{c W}} \mathbf{( m m}\right)$ & $\boldsymbol{\varepsilon}_{\mathrm{W}}$ & $\mathbf{d}_{\mathbf{c W}}(\mathbf{m m})$ \\
\hline $\mathbf{4}$ & 0.2525 & 2.13 & 0.2905 & 5.23 & 0.3063 & 10.38 \\
\hline $\mathbf{8}$ & 0.2182 & 2.16 & 0.2681 & 5.28 & 0.2902 & 10.46 \\
\hline $\mathbf{1 2}$ & 0.1923 & 2.14 & 0.2512 & 5.32 & 0.2780 & 10.52 \\
\hline $\mathbf{1 6}$ & 0.1706 & 2.20 & 0.2371 & 5.36 & 0.2677 & 10.57 \\
\hline $\mathbf{2 0}$ & $/$ & $/$ & 0.2248 & 5.39 & 0.2588 & 10.61 \\
\hline
\end{tabular}

\subsection{Pressure drop}

The results of the predicted pressure drop by Ergun [9] equation are compared to experimental values obtained with different collectors $(2,5$ and $10 \mathrm{~mm}$ ) and for different liquid and air flow rates (fig. 5). The air superficial velocity ranged between 0.08 and 0.32 $\mathrm{m} . \mathrm{s}^{-1}$ and the wet porosity between 0.31 to 0.17 (which corresponds to a liquid Reynolds number between 4 and 106). The model gives estimation with a $25 \%$ error. When the liquid flow rate exceeds 12 L. $\mathrm{min}^{-1}$ the error becomes too important, this suggests that we are operating at the boundary of the trickling regime. Under such operating conditions the liquid is no longer homogeneously distributed through the bed. This could lead to the creation of enriched liquid zones or to liquid accumulation on the grid, which may explain the important increase of the experimental pressure drop.
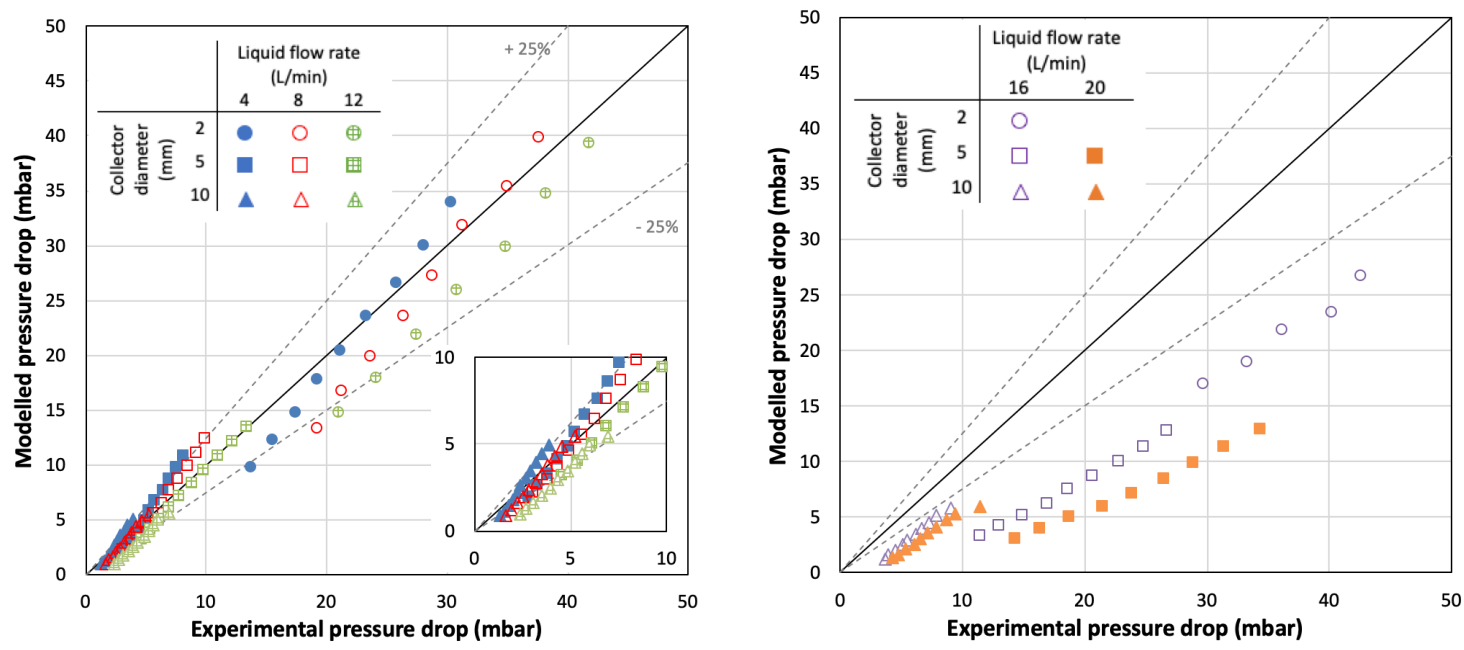

Fig. 5. Calculated values of the pressure drop with Ergun (1952) equation versus experimental values. 


\subsection{Collection efficiency}

\subsubsection{Nanoparticles collection efficiency}

In order to analyse the influence of the liquid flow rate, the air flow rate is kept constant. In these operating conditions, the wet porosity varied between 0.21 and 0.28 , which corresponds to a liquid Reynolds number between 10 and 53. For particles with diameters between 25 and $100 \mathrm{~nm}$, results (fig. 6) show that the efficiency of the dry bed is better than that of the trickle bed, and that experimental results are by far greater than those predicted by the theoretical model. This could be explained by the existence of electrostatic effects. Indeed, in a dry bed, electrostatic effects can be significant for particles in the range of 20 and 100 $\mathrm{nm}$ [23], while they can be counteracted by the presence of liquid at the collector surface. No significant influence of the liquid flow rate is observed under these conditions. Indeed, the increase of the liquid flow rate, and consequently of the liquid hold up, induces a porosity decrease responsible for a better particle collection. Another consequence is an interstitial velocity increase. As for nanoparticles the predominant collection mechanism is Brownian diffusion, a decrease of the residence time causes a lower collection efficiency. The values predicted by the model developed in this study are in agreement with the experimental values with a $10 \%$ error, which validates the approach adopted. The same tendencies are observed for other air flow rates.

The collection efficiency of the trickle granular bed was determined for three air flow rates ( $G=12,15$ and $\left.20 \mathrm{~m}^{3} \cdot \mathrm{h}^{-1}\right)$ and for four water flow rates $(L=4$, 8,12 and 20 L. $\mathrm{min}^{-1}$ ). Figure 7 gives the influence of the air flow rate with a constant liquid flow rate of $20 \mathrm{~L} \cdot \mathrm{min}^{-1}$, the same trend is observed with all the other liquid flow rates. It can be noticed that the collection efficiency curves present a minimum for particles with diameters around $100 \mathrm{~nm}$, approaching by that what is known as the "Most Penetrating Particle Size" (MPPS). In this range, the particle size is too important to be collected by the diffusion mechanism and too small to be intercepted by the collectors. The results demonstrate that lower air flow rates result in higher collection efficiencies. As the dominating collection mechanism in this range is diffusion, increasing the residence time results in a better particle collection.

\subsubsection{Modelling the collection efficiency of micronic particles}

The validity of the modelling approach was tested using experimental data obtained in a previous work [6] on the removal of $\mathrm{Al}_{2} \mathrm{O}_{3}$ micronic particles (with a mean aerodynamic diameter of $1.8 \mu \mathrm{m}$ ) by a trickle granular bed with different collector diameters (2, 5 and $10 \mathrm{~mm}$ ) and a bed thickness of $50 \mathrm{~cm}$. These measurements were conducted on the same experimental pilot presented by figure 1 .

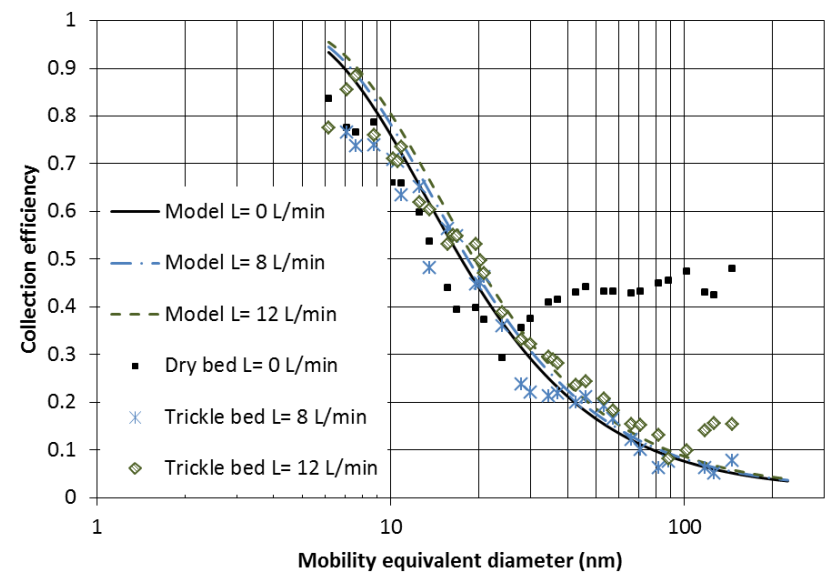

Fig. 6. Influence of liquid flow rate on the collection efficiency of the trickle granular bed for a constant air flow rate of $12 \mathrm{~m}^{3} \cdot \mathrm{h}^{-1}$ and a collector diameter of $5 \mathrm{~mm}$.

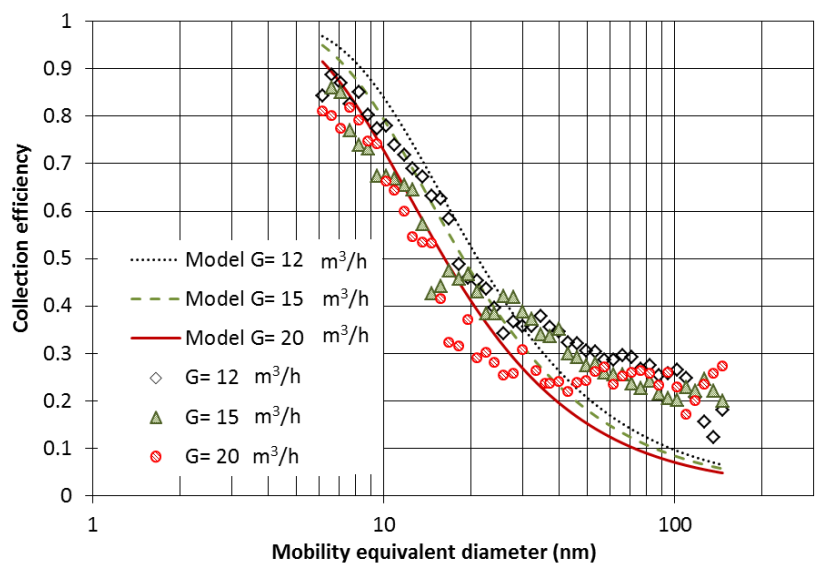

Fig. 7. Influence of air flow rate on the collection efficiency of the trickle granular bed for a constant liquid flow rate of $20 \mathrm{~L}^{\mathrm{min}} \mathrm{m}^{-1}$ and a collector diameter of $5 \mathrm{~mm}$.

The model predictions are in good agreement with the experimental results (fig. 8, 9 and 10), taking into consideration the measurements uncertainties (10\% error). Results show that the collection efficiency increases with increasing the particle diameter, due to the predominance of inertial and interception mechanisms in this size range. Using smaller collectors allows improving the collection efficiency which is in agreement with theoretical predictions and experimental observations [4]. 
Increasing the water flow rate results in an increase of the collection efficiency. This is mainly due to the decrease of the bed porosity, that will also cause an increase of the interstitial velocity, enhancing the particle collection by the inertial mechanism. In figure 10, the experimental collection efficiency of the dry bed is lower than that predicted by the model. This might be due to the increase of the collector diameter causing a decrease of the ratio between the column diameter and the collector diameter. Low ratios result in a wall effect that creates preferential passages. In the presence of liquid this effect will disappear because of the liquid hold up.

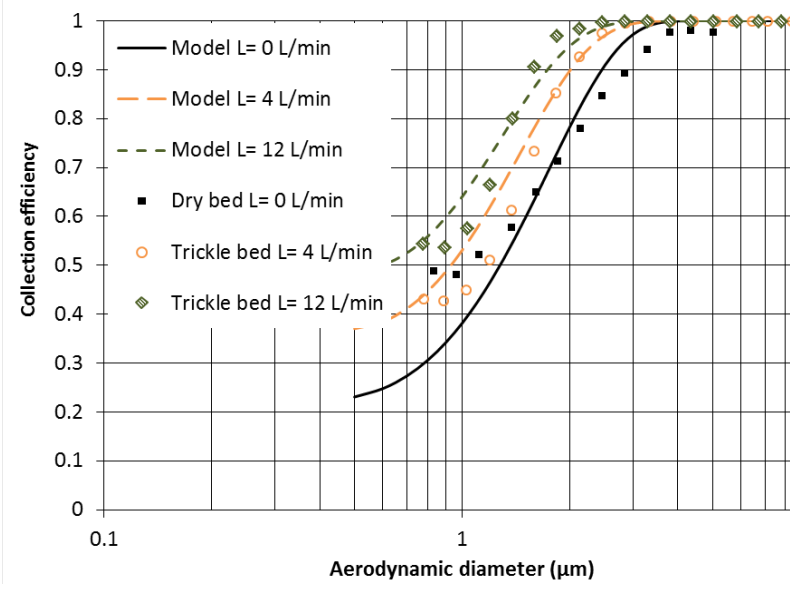

Fig. 8. Experimental and modelled collection efficiencies obtained with $2 \mathrm{~mm}$ diameter collectors and an air flow rate of $20 \mathrm{~m}^{3} \cdot \mathrm{h}^{-1}$.

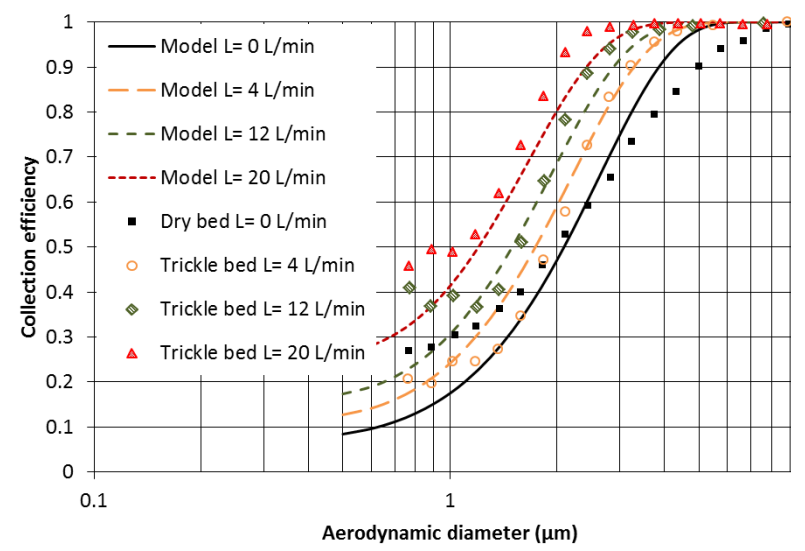

Fig. 9. Experimental and modelled collection efficiencies obtained with $5 \mathrm{~mm}$ diameter collectors and an air flow rate of $20 \mathrm{~m}^{3} \cdot \mathrm{h}^{-1}$.

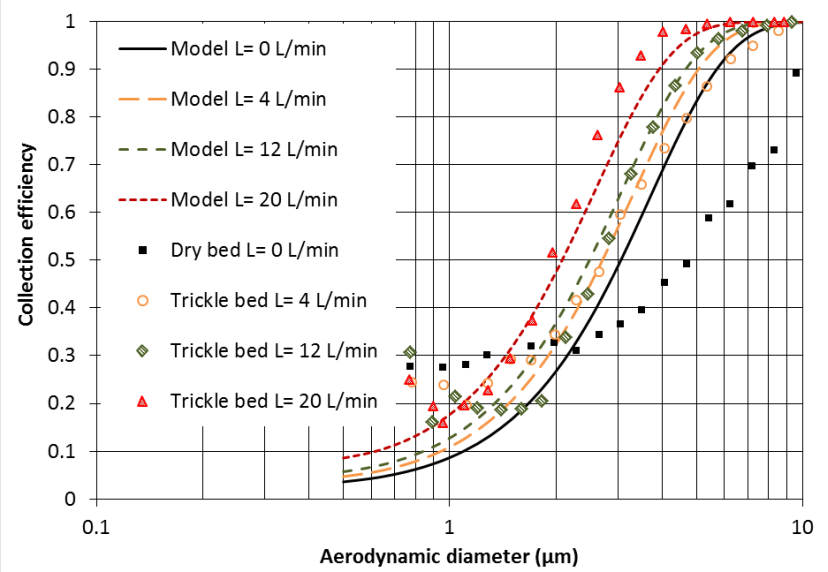

Fig. 10. Experimental and modelled collection efficiencies obtained with $10 \mathrm{~mm}$ diameter collectors and an air flow rate of $20 \mathrm{~m}^{3} \cdot \mathrm{h}^{-1}$.

\section{CONCLUSION}

This study allows to evaluate the performances of the trickle granular bed for particles filtration and to establish mathematical models for the design of the process. An approach based on the variation of the bed characteristics due to the liquid hold up turned out to be sufficient to predict the filtration efficiency and the pressure drop. This approach is only valid in the trickling regime, i.e. at low liquid and gas flow rates, as the liquid flows in the form of films over the collectors. The ability to estimate the liquid hold up is of importance as it is related to the changes of the bed characteristics. Despite a collection efficiency similar to the one of a dry granular bed for nanoparticles, it should be kept in mind that the trickle granular bed can maintain a constant pressure drop during particles loading. Moreover, performances could be optimised by increasing the bed thickness and/or using smaller collectors. This separator also presented higher efficiency for micronic particles in comparison with a dry granular bed. Increasing the liquid flow rate leads to improving the collection efficiency which is mainly linked to the decreasing bed porosity. Regarding its advantages, the trickle granular bed may be an interesting alternative for dust filtration where a limited pressure drop is required.

$\begin{array}{ll}\text { NOMENCLATURE } \\ \mathrm{a}_{\mathrm{s}} & \begin{array}{l}\text { Bed specific surface area }\left(\mathrm{m}^{2} / \mathrm{m}^{3}\right)= \\ \end{array} \\ \mathrm{C}_{\text {in }} & \begin{array}{l}\text { Dust concentration upstream the } \\ \left.\text { trickle bed (particles } / \mathrm{cm}^{3}\right)\end{array} \\ & \begin{array}{l}\text { Dust concentration downstream the } \\ \mathrm{C}_{\text {out }}\end{array} \\ & \left.\text { trickle bed (particles } / \mathrm{cm}^{3}\right) \\ \mathrm{Cu}_{\mathrm{c}} & \text { Cunningham coefficient }(-) \\ \mathrm{d}_{\mathrm{c}} & \text { Collector diameter }(\mathrm{m}) \\ \mathrm{d}_{\mathrm{cw}} & \text { Wet collector diameter }(\mathrm{m})\end{array}$




\begin{tabular}{|c|c|}
\hline$D_{\text {diff }}$ & Brownian diffusion coefficient $(\mathrm{m} / \mathrm{s})$ \\
\hline$d_{p}$ & Dust particle diameter $(\mathrm{m})$ \\
\hline$E$ & Bed filtration efficiency (-) \\
\hline $\mathrm{Eö}^{*}$ & $\begin{array}{l}\text { Modified Eötvös number }=\rho_{\mathrm{L}}{ }^{2} \mathrm{~g} \\
\mathrm{~d}_{\mathrm{c}}^{2} \varepsilon^{2} / \sigma_{\mathrm{L}}(1-\varepsilon)^{2}\end{array}$ \\
\hline $\mathrm{E}_{\mathrm{TB}}$ & Trickle bed filtration efficiency (-) \\
\hline G & Air flow rate $\left(\mathrm{m}^{3} / \mathrm{s}\right)$ \\
\hline g & Gravity acceleration $\left(\mathrm{m} / \mathrm{s}^{2}\right)$ \\
\hline$g(\varepsilon)$ & Hydrodynamic factor (-) \\
\hline $\mathrm{Ga}_{\mathrm{L}}$ & $\begin{array}{l}\text { Dimensionless liquid Galileo number } \\
=\rho_{\mathrm{L}}^{2} \mathrm{~g} \mathrm{~d}_{\mathrm{c}}^{3} / \mu_{\mathrm{L}}{ }^{2}\end{array}$ \\
\hline $\mathrm{Gr}$ & Sedimentation parameter (-) \\
\hline $\mathrm{H}$ & Bed thickness (m) \\
\hline $\mathrm{h}$ & $\begin{array}{l}\text { Total liquid hold up ( } \mathrm{m}^{3} \text { of liquid } / \mathrm{m}^{3} \\
\text { bed volume) }\end{array}$ \\
\hline$h_{\text {dyn }}$ & $\begin{array}{l}\text { Dynamic liquid hold up ( } \mathrm{m}^{3} \text { of liquid/ } \\
\mathrm{m}^{3} \text { bed volume) }\end{array}$ \\
\hline $\mathrm{h}_{\mathrm{s}}$ & $\begin{array}{l}\text { Static liquid hold up ( } \mathrm{m}^{3} \text { of liquid } / \mathrm{m}^{3} \\
\text { bed volume) }\end{array}$ \\
\hline $\mathrm{k}_{1}$ & Ergun constant (-) \\
\hline $\mathrm{k}_{2}$ & Ergun constant (-) \\
\hline$k_{B}$ & Boltzmann constant $(\mathrm{J} / \mathrm{K})$ \\
\hline $\mathrm{L}$ & Liquid flow rate $\left(\mathrm{m}^{3} / \mathrm{s}\right)$ \\
\hline $\mathrm{N}_{\mathrm{C}}$ & Number of collectors in the bed (-) \\
\hline $\mathrm{Pe}$ & Peclet number (-) \\
\hline $\mathrm{R}$ & Interception parameter (-) \\
\hline $\operatorname{Re}$ & Reynolds number $=\rho U d_{c} / \mu$ \\
\hline $\operatorname{Re}_{\mathrm{L}}$ & $\begin{array}{l}\text { Dimensionless liquid Reynolds } \\
\text { number }=\rho_{\mathrm{L}} \mathrm{U}_{\mathrm{L}} \mathrm{d}_{\mathrm{C}} / \mu_{\mathrm{L}}\end{array}$ \\
\hline St & Stokes number (-) \\
\hline $\mathrm{T}$ & Temperature (K) \\
\hline $\mathrm{U}_{\mathrm{G}}$ & Gas superficial velocity $(\mathrm{m} / \mathrm{s})$ \\
\hline $\mathrm{U}_{\mathrm{L}}$ & Liquid superficial velocity $(\mathrm{m} / \mathrm{s})$ \\
\hline$V_{\text {bed }}$ & Bed volume $\left(\mathrm{m}^{3}\right)$ \\
\hline $\mathrm{V}_{\mathrm{C}}$ & Single collector volume $\left(\mathrm{m}^{3}\right)$ \\
\hline $\mathrm{V}_{\mathrm{L}}$ & Liquid volume $\left(\mathrm{m}^{3}\right)$ \\
\hline$V_{L C}$ & $\begin{array}{l}\text { Liquid volume over a single collector } \\
\left(\mathrm{m}^{3}\right)\end{array}$ \\
\hline \multicolumn{2}{|c|}{ Greek letters } \\
\hline$\mu_{\mathrm{G}}$ & Gas viscosity (Pa.s) \\
\hline$\Delta \mathrm{P}$ & Pressure drop (Pa) \\
\hline$\varepsilon$ & Granular bed porosity (-) \\
\hline$\varepsilon_{W}$ & Wet porosity (-) \\
\hline \multirow[t]{2}{*}{$\eta_{\text {Diffusion }}$} & Unit collection efficiency \\
\hline & Brownian diffusion (-) \\
\hline$\eta_{\text {Inertial }}$ & $\begin{array}{l}\text { Unit collection efficiency by inertial } \\
\text { impaction (-) }\end{array}$ \\
\hline$\eta_{\text {Interception }}$ & $\begin{array}{l}\text { Unit collection efficiency by } \\
\text { interception (-) }\end{array}$ \\
\hline$\eta_{\text {Sedimentation }}$ & $\begin{array}{l}\text { Unit collection efficiency by } \\
\text { sedimentation (-) }\end{array}$ \\
\hline$\eta_{T}$ & Total single collector efficiency (-) \\
\hline$\rho_{\mathrm{G}}$ & Gas density $\left(\mathrm{kg} / \mathrm{m}^{3}\right)$ \\
\hline$\rho_{\mathrm{L}}$ & Liquid density $\left(\mathrm{kg} / \mathrm{m}^{3}\right)$ \\
\hline$\sigma_{L}$ & Liquid surface tension $(\mathrm{N} / \mathrm{m})$ \\
\hline
\end{tabular}

This research did not receive any specific grant from funding agencies in the public, commercial, or notfor-profit sectors.

\section{REFERENCES}

[1] Mouret G., Thomas D., Chazelet S. et al. Penetration of nanoparticles through fibrous filters perforated with defined pinholes. J Aerosol Sci. 2009;40(9):762-775.

[2] Bémer D., Morele Y., Régnier R., Filtration of ultrafine metallic particles in industry. Environ Technol. 2015;36(18):2374-2380.

[3] Ozis F., Singh M., Devinny J.et al., Removal of ultrafine and fine particulate matter from air by a granular bed filter. J Air Waste Manag Assoc. 2004;54(8):935-940.

[4] Golshahi L., Abedi J., Tan Z., Granular filtration for airborne particles: correlation between experiments and models. Can J Chem Eng. 2009;87(5):726-731.

[5] Bémer D., Subra I., Morele Y., et al., Experimental study of granular bed filtration of ultrafine particles emitted by a thermal spraying process. J Aerosol Sci. 2013;63:25-37.

[6] Thieffry G., Charvet A,. Bardin-Monnier N.,et al., Trickle bed applied to the post-treatment of blast furnace dust. Asia-Pac J Chem Eng. 2018;13:e2161.

[7] Ranade V., Chaudhari R.V., Gunjal P.R., Trickle bed reactors: reactor engineering \& applications. Oxford (UK): Elsevier; 2011.

[8] Sie S.T., Krishna R., Process development and scale up: III. Scale-up and scale-down of trickle bed processes. Rev Chem Eng. 1998;14(3):203-252.

[9] Ergun S., Fluid flow through packed columns. Chem Eng Prog. 1952;48:89-94.

[10] Ingmanson W., Andrew B., High velocity flow through fibre mats. TAPPI. 1963;3:150-155.

[11] Specchia V., Baldi G., Pressure drop and liquid holdup for two phase concurrent flow in packed beds. Chem Eng Sci. 1977;32(5):515-523.

[12] Mann L.A., Goren S.L., Aerosol capture in granular beds in the sedimentation and diffusion dominated regimes. Aerosol Sci Technol. 1984;3(2):195-213.

[13] Gal E., Tardos G., Pfeffer R., A study of inertial effects in granular bed filtration. AIChE J. 1985;31(7):1093-1104.

[14] Tien C., Ramarao B.V., Granular Filtration of Aerosols and Hydrosols. Oxford (UK): Elsevier; 2007. [15] Tardos G., Abuaf N., Gutfinger C., Dust deposition in granular bed filters: Theories and experiments. J Air Pollut Control Assoc. 1978;28(4):354-363.

[16] Otani Y., Kanaoka C., Emi H., Experimental study of aerosol filtration by the granular bed over 
a wide range of Reynolds numbers. Aerosol Sci Technol. 1989;10(3):463-474.

[17] Lee K.W., Maximum penetration of aerosol particles in granular bed filter. J Aerosol Sci. 1981;12(1):79-87.

[18] Al-Dahhan M., Highfill W., Liquid holdup measurement techniques in laboratory high pressure trickle bed reactors. Can J Chem Eng. 1999;77(4):759-765.

[19] Saez A.E., Carbonell R.G.,

Hydrodynamic Parameters for gas liquid cocurrent flow in packed beds. AIChE J. 1985;31(1):52-62.

[20] Saez A.E., Yepez M.M., Cabrera C. et al., Static liquid holdup in packed beds of spherical particles. AIChE J. 1991;37(11):1733-1736.

[21] Charpentier J.C., Favier M. , Some liquid holdup experimental data in trickle bed reactors for foaming and nonfoaming hydrocarbons. AIChE J. 1975;21(6):1213-1218.

[22] Wammes W.J.A. Middelkamp J., Huisman W.J. et al., Hydrodynamics in a cocurrent gas-liquid trickle bed at elevated pressures. AIChE J. 1991;37(12):1849-1862.

[23] Givehchi R., Li Q., Tan Z., The effect of electrostatic forces on filtration efficiency of granular filters. Powder Technol. 2015;277:135140. 